\title{
Assessement of Water Quality and Risk of Polyaromatic Hydrocarbons in Lungfish (Protopterus annectens) from Freshwaters of Ogba/Egbema/Ndoni, Rivers State, Nigeria
}

\author{
Elechi Owhoeke $^{1, \text { * }}$, Julius Nkeonyeasua Ehiwario ${ }^{2, *}$ \\ ${ }^{1}$ Department of Pure and Industrial Chemistry, University of Port Harcourt, Port Harcourt, Nigeria \\ ${ }^{2}$ Department of Science Laboratory Technology, Delta State Polytechnic, Ozoro, Nigeria
}

Email address:

elechiowhoeke@yahoo.com (E. Owhoeke), ehiwariojulius@gmail.com (J. N. Ehiwario)

${ }^{*}$ Corresponding author

To cite this article:

Elechi Owhoeke, Julius Nkeonyeasua Ehiwario. Assessement of Water Quality and Risk of Polyaromatic Hydrocarbons in Lungfish (Protopterus annectens) from Freshwaters of Ogba/Egbema/Ndoni, Rivers State, Nigeria. World Journal of Public Health.

Vol. 6, No. 1, 2021, pp. 6-12. doi: 10.11648/j.wjph.20210601.12

Received: December 1, 2020; Accepted: December 14, 2020; Published: March 10, 2021

\begin{abstract}
Water quality and health risk of polycyclic aromatic hydrocarbons in $P$. annectens from freshwaters of Egi, Egbema, and Omoku communities, in Ogba/Egbema/Ndoni local government area of Rivers State, Nigeria were examined. The PAHs were checked using gas chromatography coupled with flame ionization detector (GCFID), while the physicochemical parameters were done using standard methods. Summary of the results from the three communities indicates that TDS (Total Dissolved Solids) mean value was $98.1 \pm 16.88 \mathrm{mg} / \mathrm{l}$, TSS (Total Suspended Solid) had an average value of $68.5 \pm 10.29 \mathrm{mg} / \mathrm{l}$, turbidity and $\mathrm{pH}$ had averages of $1.6 \pm 0.011$ Unit (NTU) and 7.4 \pm 1.05 respectively. The concentrations of tPAHs were $4.415 \pm 1.34 \mu \mathrm{g} / \mathrm{kg}, 4.634 \pm 0.59 \mu \mathrm{g} / \mathrm{kg}$, and $4.859 \pm 0.69 \mu \mathrm{g} / \mathrm{kg}$ for Egi, Egbema, and Omoku communities. The major PAHs were Nap, Acn, and BbF. The cancer risk for children was 2.1E-3, 2.3E-3, and 9.5E-5 for Egi, Egbema, and Omoku while that for adults were 7.1E-4, 5.7E-4, and 2.6E-4 for Egi, Egbema, and Omoku respectively. The cPAHs with the most risk index were $\mathrm{DbA}, \mathrm{BaA}, \mathrm{BaP}$, and $\mathrm{BkF}$ respectively. The risk indexes were higher than the USEPA criterion of $10^{-6}$, indicating contamination of the fish species. It is recommended that monitoring of effluent should be done often and consumption of fish from polluted water sites should be avoided.
\end{abstract}

Keywords: Water Quality, Polycyclic Aromatic Hydrocarbons, Cancer Risk and Lungfish

\section{Introduction}

In the developed world, environmental protection agencies are more active and environmental regulations are followed strictly. The overall check on the quality of the environment and also specifically water quality should be carried out on a a schedule time or a routine assignment [1-4]. Therefore, if there is any unusual alteration in the environmental or water property, this can easily be seen and needed attention given to avoid an epidemic. This is quite different in the developing and underdeveloped countries of the world. Freshwaters are essential to inhabitants of the hinterland due to its resources especially for purposes like; recreation, source of income, and fishing port, etc. Human activities have greatly impacted the water bodies such as activities like crude oil and natural gas exploration in the oil producing communities of Nigeria [5]. There is always the release of obnoxious materials to the water bodies from their sources which could contain toxic chemicals; if absorbed by fishes could be transferred to man [6]. Aquatic organisms play a vital role as food due to their dietary composition which is good for the consumer [7]. The African Lungfish serve as food for many around sub-Saharan African, its contamination by chemicals is of major concern to researchers and scientists.

The aim of the study is to assess the physicochemical property of freshwater bodies and the health risk due to the presence of PAHs in Lungfish from Egi, Egbema, and Omoku all in Ogba/Egbema/Ndoni Local Government Council of Rivers State, Southern Nigeria. 


\section{Methodology}

\subsection{Study Area}

The local government stretches from longitude $6^{\circ} 28^{\prime} 13^{\prime \prime} \mathrm{E}$ through longitude $6^{\circ} 47^{\prime} 34^{\prime \prime} \mathrm{E}$ and latitude $5^{\circ} 9^{\prime} 42^{\prime \prime} \mathrm{N}$ through $5^{\circ} 44^{\prime} 3$ 'N. It is one of the oil-producing LGAs of the Southern region of Nigeria. It is surrounded on the West by the River Orashi and bordered on the East by the River Sombreiro. There are several fresh-waters in the area and oil fields within Onelga.

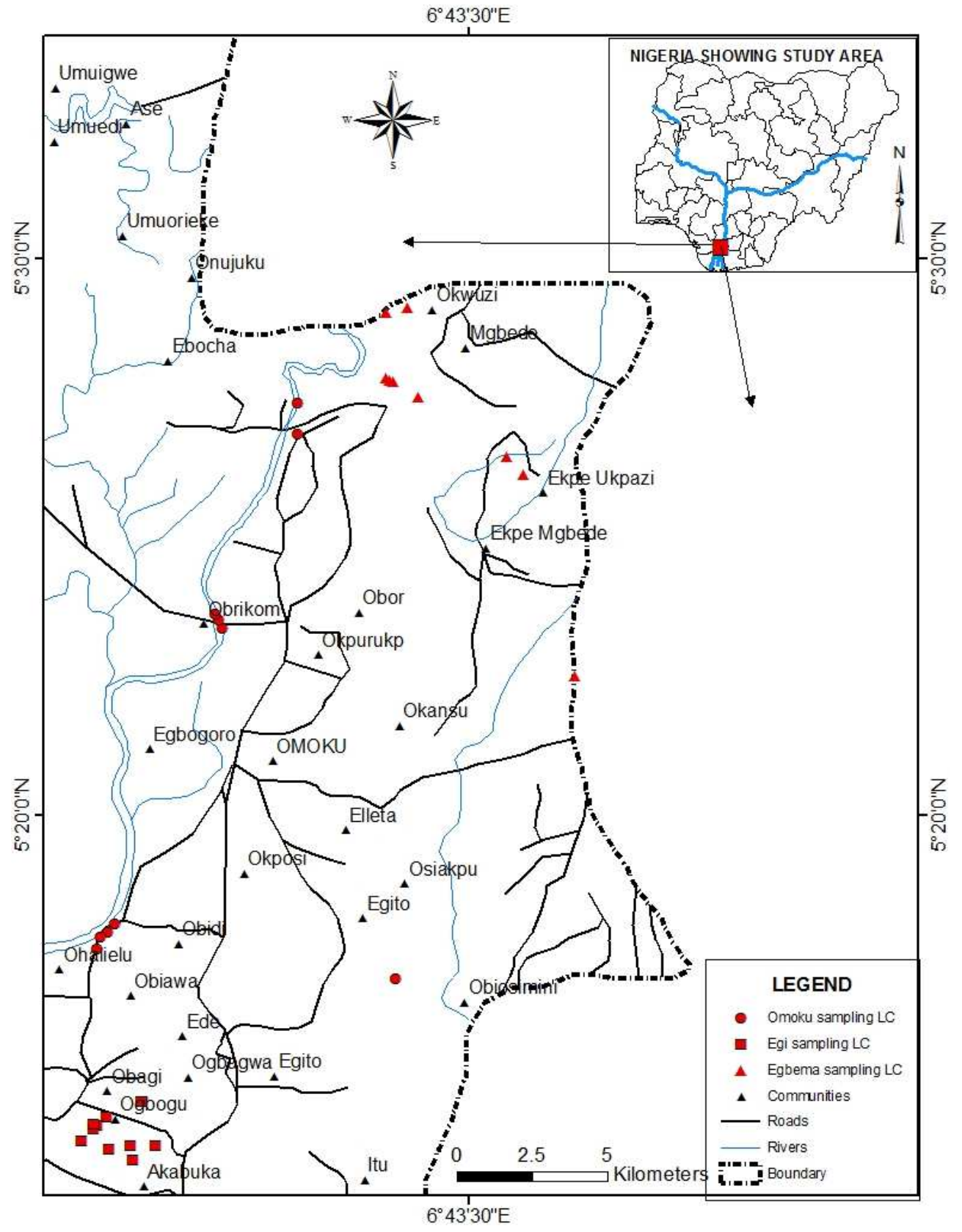

Figure 1. Map of the locations.

\subsection{Samples Collection}

The water sampling involved thirty (30) locations across the three sub-areas of from Egi, Omoku, and Egbema communities respectively. Before the samples were collected, the glass bottles were washed and dried in the sun; the glass bottles were rinsed twice with the same water samples they are to contain. In each case, samples were taken at $15 \mathrm{~cm}$ deepness below the water surface employing amber-colored 1 liter capacity glass bottles [8]. The collected samples in the bottles were instantly covered, adequately labeled, and positioned in cooler containing an ice chest with ice for more treatment and examination in the research laboratory.

Fresh Lungfish (Protopterus annectens) samples were obtained from freshwaters like the Orashi and Sombreiro rivers, creeks, lakes, and swamps in Egi, Omoku, and Egbema clans in Ogba/Egbema/Ndoni LGA, Rivers State. The fishes were transferred into a sterilized cellophane bag and taken for identification by experts at the Department of 
Animal and Environmental Biology, University of Port Harcourt.

\subsection{Determination of Physicochemical Parameters of the Freshwaters}

The $\mathrm{pH}$, turbidity, total dissolved solids (TDS), and total suspended solids (TSS) were carried out using standard procedures as described by APHA, 1992 [9].

\subsection{Sample Preparation}

The fresh fish samples obtained were sun-dried, and then later oven-dried in the laboratory to constant weight at $33^{\circ} \mathrm{C}$ for hours till completely dried. The whole fish sample (without the bones) was then grounded with a blender and preserved in a container that is impermeable to air, before the extraction process.

\subsection{Extraction of the Sample}

The extraction involved $6 \mathrm{~g}$ of the powdered extract been moved to the extraction casing and placed in the extraction compartment of the Soxhlet extractor, which made up of a $250 \mathrm{ml}$ round bottom flask, condenser, and extraction tube, well held in the heating mantle with a wide temperature range. N-hexane and dichloromethane $(3: 1 \mathrm{v} / \mathrm{v})$ was the extraction solvent which was carried out at $50^{\circ} \mathrm{C}$ for $6 \mathrm{~h}$ as described by USEPA 3540 Method [10]. The extract was concentrated in a rotary evaporator at $60^{\circ} \mathrm{C}$ to a concentration of $2 \mathrm{ml}$. This same procedure was carried out for other samples.

\subsection{Clean up of the Extracts/Gas Chromatography Analysis}

$5 \mathrm{ml}$ n-hexane was used to dissolve the concentrated extract. Activated alumina of $2.5 \mathrm{~g}$ was used to adsorb the resulting extract, and the mixture was dried under a high vacuum dryer. A glass column $(10 \mathrm{~mm}$ id $\times 40 \mathrm{~mm}$ length) was packed with activated alumina adsorbent $(7.5 \mathrm{~g})$ and the adsorbed extract was packed on the top. In series, $50 \mathrm{~mL}$ of the n-hexane, and $50 \mathrm{~mL}$ of a mixture of the n-hexane: DCM $(95: 5 \%)$ was used to elute the saturate and PAHs fractions from the adsorbed extract. The collected saturate fraction was subjected to further analysis. The PAHs fraction was reduced to a concentration of $1 \mathrm{ml}$ in an evaporator, and was transferred into a sample vial and refrigerated till further usage [11]. The procedure was repeated for all the samples.

PAHs concentration evaluation was carried out following the recommended procedures as described by Essumang et al., (2009) [12]. The sample in the vial was injected into the gas chromatography coupled with a flame ionization detector (FID). This was carried out on an HP 5890 series II GC with th following properties; fused silica capillary (HP5) of $30 \mathrm{~m}$ length, internal diameter of $0.32 \mathrm{~mm}$, and $0.25 \mu \mathrm{m}$ film diameter was $0.25 \mu \mathrm{m}$ and the rate was $6^{\circ} \mathrm{C} / \mathrm{min}$. The oven temperature was programmed from an initial temperature of $110^{\circ} \mathrm{C}(2 \mathrm{~min}$ hold $)$ to $250^{\circ} \mathrm{C}$ at the rate of $6^{\circ} \mathrm{C} / \mathrm{min}$ and was constant at $250^{\circ} \mathrm{C}$ for 25 minutes. Injector and detector temperature were kept at $285^{\circ} \mathrm{C}$ and $305^{\circ} \mathrm{C}$ respectively. The carrier gas was helium.

\subsection{Human Health Risk Assessment}

Calculated daily doses $(\mathrm{mg} / \mathrm{kg} /$ day) were estimated for adults (as the overall population) and children (as a vulnerable group) to estimated human contact through direct consumption of the fish (Eq. 1)

$$
\begin{gathered}
\mathrm{CDI}=(\text { Ef } \times \text { Ed } \times \text { Fir } \times \text { Cf } \times \text { Cff } \times \text { Cpahs }) /(\mathrm{BW} \times \mathrm{AT}) \\
\text { Cancer Risk }=\mathrm{CDI} \times \mathrm{SF}
\end{gathered}
$$

Where Cpahs $=$ metal concentration in fish, [13], Ed is the exposure duration $=65$ years for an adult and 15 years for children, $\mathrm{Ef}$ is the exposure frequency $=365$ days/year, Fir is fresh fish ingestion $=48 \mathrm{~g} /$ person $/$ day, $\mathrm{Cf}$ is the conversion factor for fresh to dry weight for fish $=0.208$, Cff $=0.001$ conversion factor from $\mu \mathrm{g}$ to $\mathrm{kg}, \mathrm{BW}$ is average body weight $=15 \mathrm{~kg}$ and $60 \mathrm{~kg}$ for children and adults, AT is the average exposure time $=\mathrm{Ed} \times \mathrm{Ef}$. day, $\mathrm{IdP}=0.73 \mathrm{mg} / \mathrm{kg}$-day, $\mathrm{BaA}=0.73 \mathrm{mg} / \mathrm{kg}$-day, $\mathrm{Chr}=0.073 \mathrm{mg} / \mathrm{kg}$-day, and $\mathrm{DbA}=7.3$ $\mathrm{mg} / \mathrm{kg}$-day [14].

\section{Result and Discussions}

\subsection{Physico-Chemical Parameters of Freshwater}

The result of the physicochemical parameters obtained from the Egi, Omoku, and Egbema communities are shown in Table 1.

\begin{tabular}{|c|c|c|c|c|}
\hline Area & TDS (mg/l) & TSS (mg/l) & Turbidity (NTU) & pH \\
\hline Egi & $119.9 \pm 14.53$ & $68.3 \pm 7.54$ & $3.7 \pm 0.00$ & $7.2 \pm 1.08$ \\
\hline Omoku & $61.4 \pm 12.40$ & $66.4 \pm 11.40$ & $0.2 \pm 0.00$ & $7.4 \pm 0.96$ \\
\hline Egbema & $113.0 \pm 23.70$ & $70.8 \pm 11.93$ & $0.8 \pm 0.00$ & $7.5 \pm 1.05$ \\
\hline Mean & $98.1 \pm 16.88$ & $68.5 \pm 10.29$ & $1.6 \pm 0.00$ & $7.4 \pm 1.05$ \\
\hline WHO (2006) & 1000 & 100 & 5 & $6.5-8.5$ \\
\hline India (EPR, 1993) & 500 & 100 & 10 & $6.5-8.5$ \\
\hline Nigeria (FMENV, 1992) & 1000 & 500 & 5 & $6.5-8.5$ \\
\hline
\end{tabular}

Table 1. Summary of Physico-chemical Properties with Permissible Limit.

TDS was $98.1 \pm 16.88 \mathrm{mg} / \mathrm{l}$ as the mean for the three areas which was lower than the limit. Alabaster and Lloyd [15], submitted that extreme concentration of suspended and dissolved solid influence the toxicity of the water to aquatic organisms, this is because it reduces the quality of the water, affects processes that leads to photosynthesis, and increases the amount of sediment/depth of water. The mean of total suspended solids for the three areas were Egi; $68.3 \pm 7.54$ 
$\mathrm{mg} / \mathrm{l}, \quad$ Omoku; $66.4 \pm 11.40 \mathrm{mg} / \mathrm{l}$, and Egbema area; $70.8 \pm 11.93 \mathrm{mg} / \mathrm{l}$. The TSS is low compared with the Federal Ministry of Environment (FMENV) and WHO's standard of 2006. These values were higher than reports by Ewa et al., (2011) [16] on the Omoku creek (22.3 mg/l).

The mean Turbidity value was $1.6 \pm 0.00$ which was lower than WHO's standard of 5 NTU. This is also relatively lower than work by Ewa et al. (2011), where they reported 29.30 NTU on Omoku creek. This could be attributed to the water current from the flooding which washed away most of the organic particles on the surface of these water bodies. The mean of $\mathrm{pH}$ were within the range recommended by WHO (2006) [17] for drinking water. Although the values reveal that the surface water samples are slightly basic, it is in agreement with what was reported by other researchers in a similar study [18]. Chinedu et al., (2011) [19], (6.0 \pm 0.52 to $7.2 \pm 0.52$ ) on surface water around Ota, southwest Nigeria. This result recorded for the surface water is agreeable to the fact that ONELGA is an oil and gas production area that is characterized by industries that discharge effluents made of organic matter.

\subsection{Polycyclic Aromatic Hydrocarbons in Lungfish}

The table below revealed the result of PAHs presence in the lungfish from the study area.

Table 2. Summary measurements of PAHs in Protopterus annecteens samples $(\mu \mathrm{g} / \mathrm{kg})$.

\begin{tabular}{llll}
\hline \multirow{2}{*}{ PAHs } & Egi & Egbema & Omoku \\
\cline { 2 - 4 } & $0.967 \pm 0.12$ & $\mathrm{Nd}$ & $0.789 \pm 0.07$ \\
\hline Nap & $0.286 \pm 0.03$ & $0.124 \pm 0.02$ & $0.349 \pm 0.03$ \\
Ace & $\mathrm{Nd}$ & $0.774 \pm 0.07$ & $0.677 \pm 0.05$ \\
Flo & $0.467 \pm 0.14$ & $\mathrm{Nd}$ & $0.420 \pm 0.09$ \\
Ant & $0.151 \pm 0.11$ & $0.180 \pm 0.09$ & $0.256 \pm 0.08$ \\
Phe & $0.823 \pm 0.21$ & $\mathrm{Nd}$ & $0.017 \pm 0.00$ \\
Flu & $\mathrm{Nd}$ & $0.895 \pm 0.08$ & $0.020 \pm 0.00$ \\
$\mathrm{Pyr}$ & $\mathrm{Nd}$ & $0.246 \pm 0.03$ & $\mathrm{Nd}$ \\
$\mathrm{BaA}$ & $\mathrm{Nd}$ & $\mathrm{Nd}$ & $0.867 \pm 0.06$ \\
$\mathrm{Chr}$ & $\mathrm{Nd}$ & $\mathrm{Nd}$ & $\mathrm{Nd}$ \\
$\mathrm{BbF}$ & $0.321 \pm 0.23$ & $0.987 \pm 0.15$ & $\mathrm{Nd}$ \\
$\mathrm{BkF}$ & $0.216 \pm 0.05$ & $0.261 \pm 0.00$ & $0.754 \pm 0.13$ \\
$\mathrm{BaP}$ & $0.201 \pm 0.09$ & $0.067 \pm 0.01$ & $0.033 \pm 0.01$ \\
$\mathrm{IdP}$ & $0.456 \pm 0.19$ & $0.423 \pm 0.04$ & $\mathrm{Nd}$ \\
$\mathrm{DbA}$ & $0.290 \pm 0.11$ & $0.241 \pm 0.06$ & $0.026 \pm 0.01$ \\
$\mathrm{BgP}$ & $0.237 \pm 0.06$ & $0.375 \pm 0.04$ & $0.651 \pm 0.16$ \\
tPAHs & $4.415 \pm 1.34$ & $4.634 \pm 0.59$ & $4.859 \pm 0.69$ \\
\hline $\mathrm{N}$ & & & \\
\hline
\end{tabular}

Note: $\mathrm{Nd}=\mathrm{Not}$ Detected, Nap.=Naphthalene, Ace.=Acenaphthylene, Acn=Acenaphthene, Flo.=Fluorene, Ant.=Anthracene, Phe. $=$ Phenanthrene, Flu. $=$ Fluoranthene, Pyr. $=$ Pyrene, $\mathrm{BaA}=$ Benz (a) Anthracene, $\mathrm{Chr} .=$ Chrysene, $\mathrm{BbF}=\mathrm{Benzo}(\mathrm{b})$ Fluoranthene, $\mathrm{BkF}=\mathrm{Benzo}(\mathrm{k})$ Fluoranthene, $\mathrm{BaP}=\mathrm{Benzo}(\mathrm{a})$ Pyrene, IdP=Indeno (1,2,3-cd) Pyrene, DbA=Dibenz $(\mathrm{a}, \mathrm{h})$ Anthracene, $\mathrm{BgP}=\operatorname{Benzo}(\mathrm{g}, \mathrm{h}, \mathrm{i})$ Perylene.

The distribution of PAHs in $P$. annectens sampled from different sites is given in Table 2. The total PAHs detected for the different sites were $4.415 \pm 1.34 \mu \mathrm{g} / \mathrm{kg}, 4.634 \pm 0.59 \mu \mathrm{g} / \mathrm{kg}$, $4.859 \pm 0.69 \mu \mathrm{g} / \mathrm{kg}$, for Egi, Egbema, and Omoku respectively. The values ranged from 0.00 to $0.987 \mu \mathrm{g} / \mathrm{kg}$. The prominent PAHs were Nap $(0.967 \pm 0.12 \mu \mathrm{g} / \mathrm{kg})$ and Phe $(0.823 \pm 0.21$ $\mu \mathrm{g} / \mathrm{kg})$ for Egi sites, BbF $(0.987 \pm 0.15 \mu \mathrm{g} / \mathrm{kg})$ and Flu $(0.895 \pm 0.08 \mu \mathrm{g} / \mathrm{kg})$ for Egbema sites, and $\mathrm{BaA}(0.867 \pm 0.06$ $\mu \mathrm{g} / \mathrm{kg})$ and Nap $(0.789 \pm 0.07 \mu \mathrm{g} / \mathrm{kg})$ for Omoku sites. Chr was not detected in all the sites. This result was lower than reports by Mihalca et al., (2011) [20] (77.3 $\mu \mathrm{g} / \mathrm{kg})$ on smoked fishes. Mirsadeghi et al., (2011) [21] reported a higher value of $3.34 \pm 0.77$ to $46.85 \pm 5.50 \mu \mathrm{g} / \mathrm{kg}$ in $A$. granosa. Though reports by Olabemiwo et al., (2011), [22] (0.814 $\mu \mathrm{g} / \mathrm{kg}$ ) on $T$. guineensis was lower. The range of values indicates human activities have impacted the freshwater bodies.

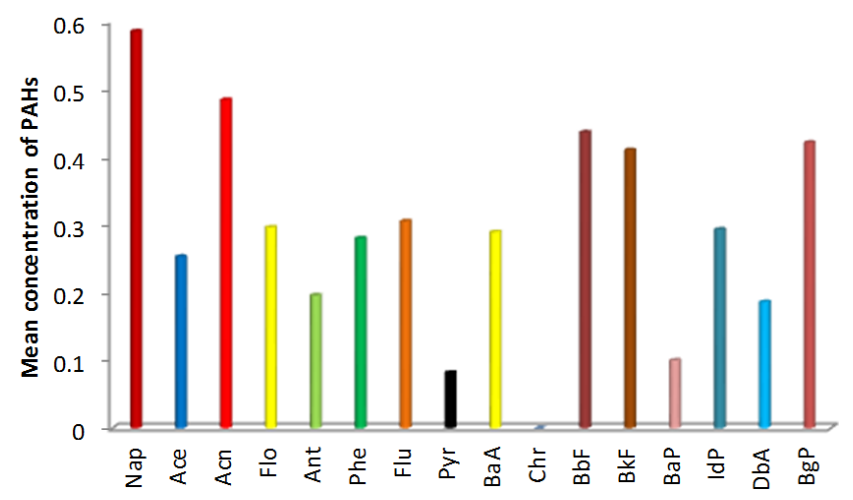

Figure 2. Mean concentration of PAHs across the study area.

The mean of PAHs reveals that the PAHs with the highest concentrations were Nap, Acn, $\mathrm{BbF}$, and $\mathrm{BgP}$ respectively. The result also shows that the non-carcinogenic PAHs were of higher concentration than the cPAHs.

Table 3. Calculated daily intake (CDI) and cancer risk of PAHs estimate for children.

\begin{tabular}{llll}
\hline & Egi & Egbema & Omoku \\
\cline { 2 - 4 } & & CDI value & \\
\hline $\mathrm{Chr}$ & - & - & - \\
$\mathrm{BaA}$ & - & - & $5.8 \mathrm{E}-4$ \\
$\mathrm{BbF}$ & $2.1 \mathrm{E}-4$ & $6.6 \mathrm{E}-4$ & - \\
$\mathrm{BkF}$ & $1.4 \mathrm{E}-4$ & $1.7 \mathrm{E}-4$ & $5.0 \mathrm{E}-4$ \\
$\mathrm{BaP}$ & $1.3 \mathrm{E}-4$ & $4.5 \mathrm{E}-5$ & $2.2 \mathrm{E}-5$ \\
$\mathrm{IdP}$ & $3.0 \mathrm{E}-4$ & $2.8 \mathrm{E}-4$ & - \\
$\mathrm{DbA}$ & $1.9 \mathrm{E}-4$ & $1.6 \mathrm{E}-4$ & $1.7 \mathrm{E}-5$ \\
& & Cancer Risk & \\
$\mathrm{Chr}$ & - & - & - \\
$\mathrm{BaA}$ & - & - & $4.2 \mathrm{E}-4$ \\
$\mathrm{BbF}$ & $1.5 \mathrm{E}-4$ & $4.8 \mathrm{E}-4$ & - \\
$\mathrm{BkF}$ & $1.0 \mathrm{E}-4$ & $1.2 \mathrm{E}-4$ & $3.6 \mathrm{E}-4$ \\
$\mathrm{BaP}$ & $2.2 \mathrm{E}-4$ & $3.3 \mathrm{E}-4$ & $1.6 \mathrm{E}-4$ \\
$\mathrm{IdP}$ & $2.2 \mathrm{E}-4$ & $2.0 \mathrm{E}-4$ & - \\
$\mathrm{DbA}$ & $1.4 \mathrm{E}-3$ & $1.2 \mathrm{E}-3$ & $1.2 \mathrm{E}-5$ \\
$\mathrm{tPAHs}$ & $2.1 \mathrm{E}-3$ & $2.3 \mathrm{E}-3$ & $9.5 \mathrm{E}-4$ \\
\hline
\end{tabular}



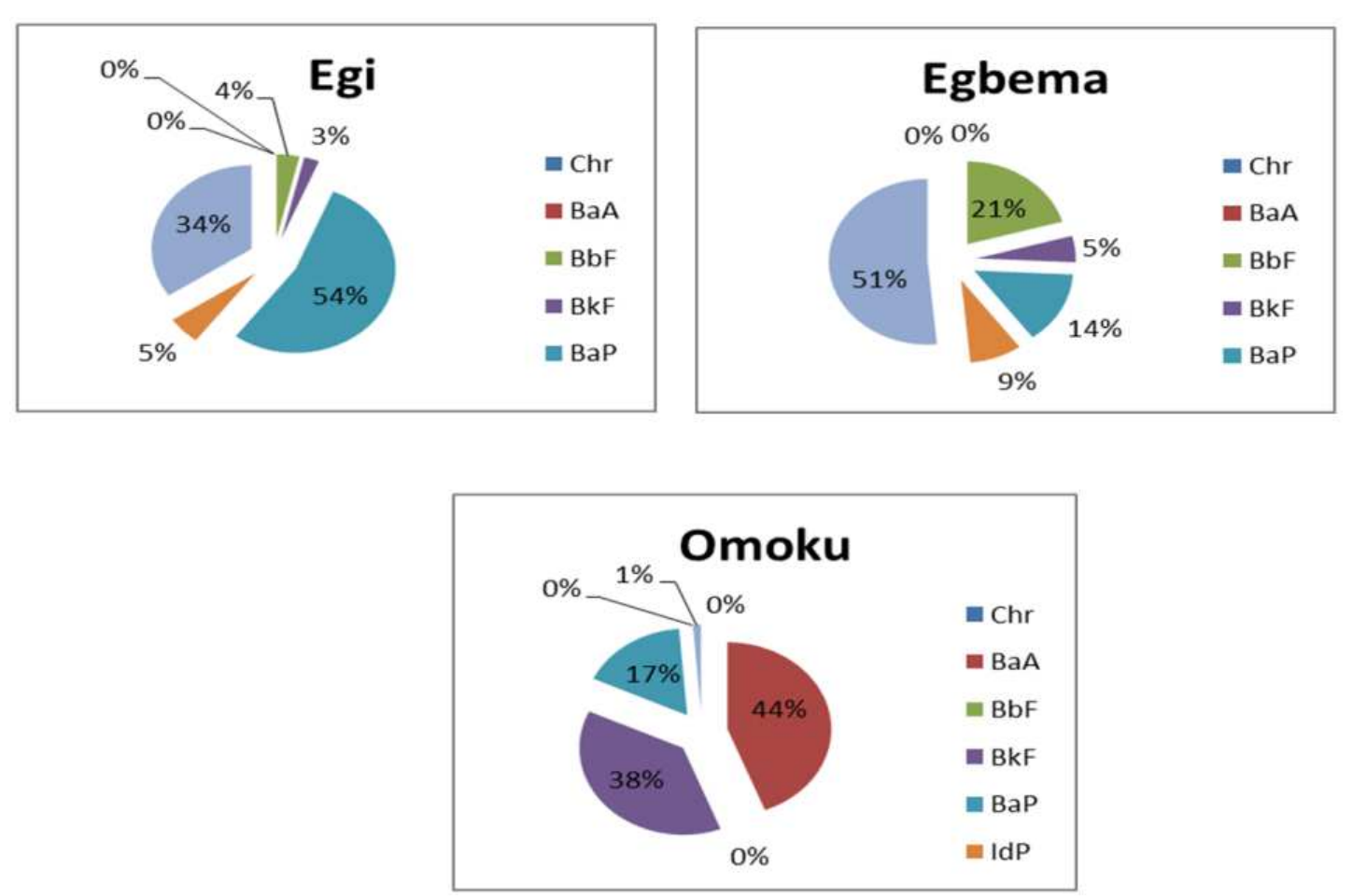

Figure 3. Percentage representation of the cancer risk of individual cPAHs in children.

The risk of PAHs in lungfish for children was high across the three communities studied with values at $10^{-3}$ to $10^{-4}$. The total cPAHs CR values were 2.1E-3, 2.3E-3, and 9.5E-4 for Egi, Egbema, and Omoku. The Egi samples had the highest risk for $\mathrm{BaP}$, Egbema was DbA, while Omoku was for BaA. It was lower than reports by Mirsadeghi et al., (2011) [22] (2.67 x 10 $\left.0^{-2}\right)$. These values are higher than the USEPA risk management criterion. The risk management range of USEPA for greater cancer risk is $1 \mathrm{x}$ $10^{-6}$, which indicates the greater cancer risk signifying to one additional cancer in a populace of one million people.

This standard predicts that, for every 1,000,000 population eating fish or shellfish containing certain cPAHs at a certain ingestion rate estimated in $\mathrm{g} /$ day for 70 years, it will amount to only one additional case of cancer.

\section{Egi}

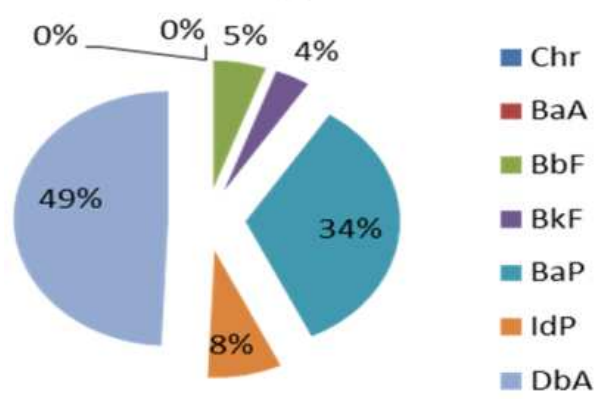

\section{Egbema}

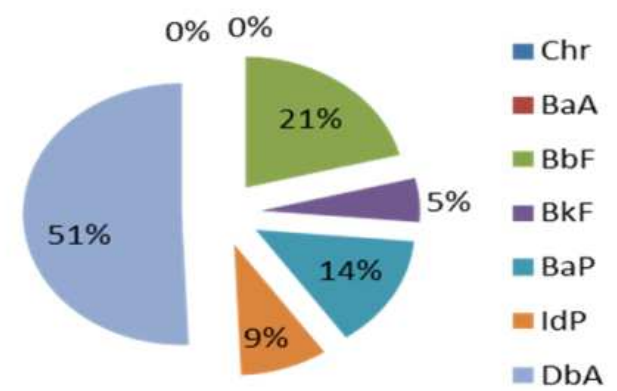

\section{Omoku}

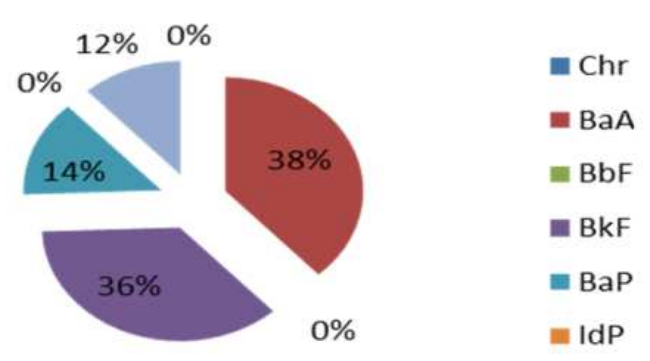

Figure 4. Percentage representation of the cancer risk of individual cPAHs in Adults. 
Table 4. Calculated daily intake (CDI) and cancer risk of PAHs estimate for Adults.

\begin{tabular}{llll}
\hline & Egi & Egbema & Omoku \\
\cline { 2 - 4 } & & CDI value & \\
\hline $\mathrm{Chr}$ & - & - & - \\
$\mathrm{BaA}$ & - & - & $1.4 \mathrm{E}-4$ \\
$\mathrm{BbF}$ & $5.3 \mathrm{E}-5$ & $1.6 \mathrm{E}-4$ & - \\
$\mathrm{BkF}$ & $3.6 \mathrm{E}-5$ & $4.3 \mathrm{E}-5$ & $1.3 \mathrm{E}-4$ \\
$\mathrm{BaP}$ & $3.3 \mathrm{E}-5$ & $1.1 \mathrm{E}-5$ & $5.0 \mathrm{E}-6$ \\
$\mathrm{IdP}$ & $7.6 \mathrm{E}-5$ & $7.0 \mathrm{E}-5$ & - \\
$\mathrm{DbA}$ & $4.8 \mathrm{E}-5$ & $14.0 \mathrm{E}-5$ & $4.3 \mathrm{E}-6$ \\
& & Cancer Risk & \\
$\mathrm{Chr}$ & - & - & - \\
$\mathrm{BaA}$ & - & - & $1.0 \mathrm{E}-4$ \\
$\mathrm{BbF}$ & $3.9 \mathrm{E}-5$ & $1.2 \mathrm{E}-4$ & - \\
$\mathrm{BkF}$ & $2.6 \mathrm{E}-5$ & $3.1 \mathrm{E}-5$ & $9.5 \mathrm{E}-5$ \\
$\mathrm{BaP}$ & $2.4 \mathrm{E}-4$ & $8.0 \mathrm{E}-5$ & $3.6 \mathrm{E}-5$ \\
$\mathrm{IdP}$ & $5.5 \mathrm{E}-5$ & $5.1 \mathrm{E}-5$ & - \\
$\mathrm{DbA}$ & $3.5 \mathrm{E}-4$ & $2.9 \mathrm{E}-4$ & $3.1 \mathrm{E}-5$ \\
$\mathrm{tPAHs}$ & $7.1 \mathrm{E}-4$ & $5.7 \mathrm{E}-4$ & $2.6 \mathrm{E}-4$ \\
\hline
\end{tabular}

The cancer risk of tPAHs in lungfish for adults was 7.1E4 for Egi, 5.7E-4 for Egbema, and 2.6E-4 for Omoku respectively. The PAHs of prominence in risk were DbA, $\mathrm{BaA}, \mathrm{BaP}$, and $\mathrm{BkF}$. These risk values were above the USEPA management criterion levels which indicate risk of cancer for 1 person in every 1 million persons for adults. Though there may be a concern for consumers of such fishes since the probability of consuming it on daily basis is low, then such risk may be minimal. There is a need for actions from stakeholders to check, reduce, and eliminate possible sources of water contamination within the study area.

\section{Conclusions}

It could be concluded from the above findings, that the samples of Pannectens were contaminated by individual PAHs to certain concentrations. These levels could be attributed to human activities which are dominated by oil and gas exploration. Also, that the concentrations detected might be of possible cancer risk if consumed regularly by the locals of the study area. Therefore monitoring the presence and concentrations of PAHs in freshwaters and fishes within the study area should be considered important, in order to check the possible danger that may emanate in the near future. It is recommended that adequate attention should be paid to the consumption of fresh fish from polluted water bodies in the study area.

\section{References}

[1] Ekpete AO, Owhoeke E. Risk assessment of heavy metals in crops and soil from a dumpsite in Rumuolumeni, Port Harcourt. Journal of Applied Chemical Science International, 2019; 10: 45-52 2019.

[2] Owhoeke, E., Horsfall Jnr, M., Osu, C. I Source apportionment and Health Risk of heavy metals in Contaminated Agricultural soil from Egi, Rivers State,
Nigeria. Science journal of Analytical Chemistry,. 2019; 6: 98103.

[3] U.S. EPA. (U.S. Environmental Protection Agency). Environmental indicators of water quality in the United States. EPA 841-R-96-002. USEPA, Office of water (4503F), U.S. Government Printing Office, Washington, D. C., USA, 1996.

[4] Robson AJ, Neal C. A Summary of Regional Water Quality for Eastern UK Rivers. Science of the Total Environment 1997; 194 \& 195: 15-39.

[5] Owhoeke, E., Horsfall Jnr, M., Osu, C. I Source Tracking and Carcinogenic Risk of Polycyclic Aromatic Hydrocarbons in Contaminated Farmlands from Egi, Niger Delta, Nigeria. Journal of Drug Design and Medicinal Chemistry. 2019; 4: 61-66.

[6] Freeman DJ, Catteil FCR. Wood Burning as Source of Atmospheric Polycyclic Aromatic Hydrocarbons. Environment, Science and Technology, 1990; 24: 1581-1585.

[7] Adekunle AS, Eniola ITK. (2008). Impact of Industrial Effluents on Quality of Segment of Asa River Within an Industrial Estate in Ilorin, Nigeria New York Science Journal, 2008; 1: 17-21

[8] Ana GREE, Sridhar MKC, Emerole GO. (2010). Contamination of Surface Water by Polycyclic Aromatic Hydrocarbons in two Nigerian Coastal Communities. Journal of Environmental Health Research, 2010; 2: 77-86.

[9] APHA. Standard Methods for the Examination of Water and Wastewater, $18^{\text {th }}$ Edition, American Public Health Association, Washington, DC, 1992.

[10] USEPA. Soxhlet Extraction-Method, 354. US-EPA, "Risk Characterization Handbook," US Envi- ronmental Protection Agency, Washington DC, 2000.

http://www.epa.gov/spc/pdfs/rchandbk.pdf. 1994.

[11] Burford MD, (1993). Factors controlling quantitative supercritical fluid extraction of environmental sample. Journal of Chromatogram., 1993; 642: 301-317.

[12] Essumang, DK, Adokoh CK, Afriyie J, Mensah E. Sources Assessment and Analysis of Polycyclic Aromatic Hydrocarbons (PAHs) in the Oblogo Waste disposal sites and some water bodies in and around the Accra Metropolis of Ghana. Journal of Water Resources and Protection, 2009; 1: 456-468.

[13] Emrah C. Health Risk Assessment of Trace Metals, PAHs and Trihalomethanes in Drinking Water of cankiri, Turkey. EJourney of Chemistry, 2012; 4: 1976-1991.

[14] Inam E, Owhoeke E, Essien JP. Human carcinogenic risk assessment of polycyclic aromatic hydrocarbons in freshwater samples from Ogba/Egbema/Ndoni communities in rivers state, Nigeria. Journal of Chemical Society of Nigeria: 2014; 2: $15-22$.

[15] Alabaster JS, Lloyd R. Water Quality Criteria for Freshwater Fish. $2^{\text {nd }}$ edition. London: Food and Agriculture Organization of the United Nations, 1982; 361.

[16] Ewa EE, Iwara AI, Adeyemi JA, Eja EI, Ajake AO, Out CA. Impact of Industrial Activities on Water Quality of Omoku Creek. Sacha Journal of Environmental Studies, 2011; 2: 8-11. 
[17] World Health Organization. Guidelines for Drinking-Water Quality, 2nd Edition, Vol. 2 - Health criteria and other supporting information. WHO, Geneva, Switzerland. 2006.

[18] Edimeh, P. O., Eneji, I. S., Oketunde, O. F. and Sha'ato, R. (2011). Physico-chemical parameters and some Heavy metals content of Rivers Inachalo and Niger in Idah, Kogi State. Journal of Chemical Society of Nigeria, 36 (1): 95-101.

[19] Chinedu, NS, Nwinyi CO, Oluwadamisi, YA, Eze NV. (2011). Assessment of Water quality in Canaanland, Ota, South West Nigeria. Agric. Biol. N. A. M. S 2011; 4: 577-58.

[20] Mihalca GI, Tița O, Tița M, Mihalca A. Polycyclic aromatic hydrocarbons (PAHs) in smoked fish from three smokehouses in Brasov county. Journal of Agroalimentary Processes and Technologies, 2011; 4: 392-397.
[21] Mirsadeghi AS, Zakaria PM, Yap KC, Shahbazi A. Risk Assessment for the Daily Intake of Polycyclic Aromatic Hydrocarbons from Ingestion of Cockle (Anadara Granosa) and Exposure to Contaminated Water and Sediments along the West Coast of Peninsular Malaysia. Journal of Environmental Sciences, 2010; 3: 336-345.

[22] Olabemiwo, O. M., Alade, A. O., Tella, A. C. Adediran GO. Assessment of polycyclic aromatic hydrocarbons in marine organisms from aromatic hydrocarbons content in smoked C. the Adriatic Sea, Italy. Chemosphere., 66: 1904-1910. C. gariepinnus and $\mathrm{T}$. guineensis fish species available in Western Nigeria. International Journal of Basic and Applied Sciences IJBAS-IJENS., 2011; 2: 135-150. 